\title{
Gender Dynamics and Jury Deliberations
}

\author{
Nancy S. Marder
}

The dynamics of jury deliberations have received limited attention from the legal community, perhaps because they occur behind closed doors. ${ }^{1}$ But social scientists' empirical studies provide a key to understanding the effects that group dynamics have on the deliberation process. ${ }^{2}$ One pattern that social scientists' studies of mock juries have identified is that women's participation rate is significantly lower than men's participation rate during deliberations. ${ }^{3}$

Part I of this Note examines the findings of these empirical studies, and Part II argues that the jury cannot perform its fact-finding, interpretative, or educational functions effectively if it fails to consider the views of all its members. Women generally need to speak more and men generally need to listen more if the jury is to engage in effective group deliberations that will allow for the articulation of a range of community values and the rendering of accurate verdicts. Representativeness and accuracy are critical because both the plaintiff and defendant depend upon the jury's ability to discern the truth and to mete out justice.

Part III draws from the findings of organizational behavior and offers recommendations to reduce the detrimental effects of gender-related be-

1. The legal community's interest in jury deliberations has focused primarily on the predeliberation selection of jurors. Lawyers want to select jurors who have characteristics suggesting that they will be sympathetic to the lawyers' clients. They want to be able to predict which jurors will vote in the client's favor in the deliberation room. However, lawyers have paid only limited attention to considering how the jurors will interact with each other during deliberations and how the group deliberation process will affect individual jurors' votes.

One of the most publicized examples of jury selection was for the Harrisburg conspiracy trial, in which defendants were charged with conspiring to raid draft boards, destroy records, kidnap Henry Kissinger, and blow up heating tunnels in Washington, D.C. The defense attorneys relied on a team of social scientists and activists to develop juror profiles and to select jurors who would be sympathetic to the case. The team analyzed background characteristics, such as age, race, religion, and sex, to try to predict jurors' sympathies. Schulman, Shaver, Colman, Emrich \& Christie, Recipe for a Jury, Psyc:Hot.ogy Tonay, May 1973, at 37.

This emphasis on pre-deliberation selection may begin to change as lawyers learn more about the deliberation process. Recently, lawyers and other television viewers had the rare opportunity to witness an actual jury deliberation. The case concerned Leroy Reed, a man with limited intelligence, a second grade reading ability, and a previous felony conviction, who was charged with illegal possession of a handgun. Frontline obtained permission to film the actual jury deliberations, which lasted approximately two and one-half hours and were condensed to an hour for television. Frontline: Inside the Jury Room (WGBH television broadcast, Apr. 8, 1986).

2. See generally Davis, Bray \& Holt, The Empirical Study of Decision Processes in Juries: A Critical Review, in Law, Justice and the Individual in Society: Psychological and Legal, Issues 341-51 (J. Tapp \& F. Levine eds. 1977) (review of empirical studies on jury deliberations).

3. See infra notes 15-16 and accompanying text. Throughout this Note, participation or participation rate will refer to a measure of verbal participation, or the amount a person talks. 
havior. The court has several means by which it can educate jurors about the need for male and female jurors to speak and to listen during deliberations. The court can use the juror handbook, introductory videotape or film, and questions during voir dire to teach jurors to be aware of who is participating and who is silent. It can officially charge the foreperson and other jurors to encourage those who are silent to speak and those who are dominating to listen. Education about group dynamics is critical both to the litigants, whose case is being decided, and to the jurors, whose jury duty can teach positive or negative lessons about democracy.

\section{Gender and Participation Rates}

Most jury studies analyze the effects of gender on an individual level, attempting to establish a relation between gender and an individual's biases. ${ }^{4}$ For example, one study found that male jurors judged attractive female defendants guilty less often, assigned them lighter punishments, and rated them better-liked than their unattractive counterparts. ${ }^{5}$ Such studies, however, fail to recognize that jury deliberations are a group process, and that the group decision is not simply a sum of the biases that individuals bring to the deliberations. ${ }^{8}$ Consequently, it is important to study the effects of gender within the group decision-making process.

4. See, e.g., Costantini, Mallery \& Yapundich, Gender and Juror Partiality: Are Women More Likely To Prejudge Guilt?, 67 Judicature 121, 126 (1983) (women show greater propensity than men to prejudge defendant guilty); Stephan, Sex Prejudice in Jury Simulation, $88 \mathrm{~J}$. Psychologr 305, 306 (1974) (jurors less likely to find defendant of their own sex guilty).

5. Efran, The Effect of Physical Appearance on the Judgment of Guilt, Interpersonal Attraction, and Severity of Recommended Punishment in a Simulated Jury Task, 8 J. Res. Personality 45 (1974); see also Sigall \& Ostrove, Beautiful but Dangerous: Effects of Offender Attractiveness and Nature of the Crime on Juridic Judgment, 31 J. PERsonal,ITy \& Soc. Psychology 410 (1975) (both men and women more likely to give lenient treatment to attractive defendants than to unattractive defendants when crime is unrelated to attractiveness).

6. The premise of such studies is that groups are merely the sum of their parts. Foss suggests that such studies should not even be called simulated juror studies: "It is not clear whether we can even meaningfully speak of simulated jurors without employing a group deliberation. Investigations of these individual phenomena would be more appropriately referred to as studies of individual judgment rather than of simulated jurors." Foss, Group Decision Processes in the Simulated Trial Jury, 39 SOCIOMETRy 305, 305 n.1 (1976); see also Izzett \& Leginski, Group Discussion and the Influence of Defendant Characteristics in a Simulated Jury Setting, 93 J. Soc. Psychology 271, 276 (1974) (after group discussion, mock jurors assigned unattractive defendant more lenient sentence than before group discussion).

In their seminal work on the jury, Kalven and Zeisel overlooked jury deliberations completely. Their findings suggested that jurors made decisions before deliberations began. H. KALveN \& $H$. ZeISEl, The AmERICAN JuRy 488 (1966). The authors may have overlooked the role of the deliberations because they were working from judges' assessments of juries' verdicts, without access to data about the deliberations. Their earlier efforts to record actual jury deliberations, which were thwarted by Congress, speak to their recognition of the importance of jury deliberations. Recording of Jury Deliberations: Hearings on S. Res. 58 Before the Subcomm. to Investigate the Administration of the Internal Security Act and Other Internal Security Laws of the Senate Comm. on the Judiciary, 84th Cong., 1st Sess. 43 (1955) (testimony of Professor Harry Kalven). The hearings led to a statute forbidding the recording or observation of jury deliberations in federal courts. See 18 U.S.G. $\$ 1508$ (1982). 
In jury deliberations, gender is important from the moment jurors enter the jury room and decide where to sit. One important finding that emerges from empirical studies is that the jury usually selects the foreperson from one of the two people seated at either end of the table. ${ }^{7}$ Men are more likely than women to assume the end positions. ${ }^{8}$ Not surprisingly, men are also more likely than women to be selected as the foreperson, ${ }^{9}$ though their selection is not due solely to their seating choice. ${ }^{10}$

The foreperson can play a critical role in leading the jury to a verdict. $\mathrm{He}$ is in a unique position from which to influence the style and direction of the discussion and usually participates more than any other juror. ${ }^{11}$ In more than one study, the foreperson spoke nearly three times as much as the average juror. ${ }^{12}$ Even though the foreperson frequently summarized

7. According to one study in small group behavior, "the leader usually sat at an end position" at the rectangular table. Sommer, Leadership and Group Geography, 24 Sociometry 99, 102 (1961). Another study found that "[t]he leader usually occupies the head of the table . . . and conversely the person who sits at the head of the table is usually perceived as the leader." M. SHAw, Group DYNAMICs 136 (1976). For jury studies on seating that are still regarded as leaders in the field despite the passage of time, see Strodtbeck \& Hook, The Social Dimensions of a Twelve-Man Jury Table, 24 SocIomETRY 397, 400 (1961) (in 32 out of 69 experimental jury deliberations, foreperson was selected from one of two persons seated at ends of table); C. Hawkins, Interaction and Coalition Realignments in Consensus-Seeking Groups: A Study of Experimental Jury Deliberations 23 (Aug. 17, 1960) (unpublished doctoral dissertation, University of Chicago) (among 69 civil juries, it was three times more likely than chance that foreperson would be selected from one of two jurors occupying end position at table). Recent manuals follow the conclusions reached in these early findings. See, e.g., L. Smith \& L. Malandro, Courtroom Communication Strategies $§ 4.47$, at 423 (1985) ("Those jurors who sit at the end of the table ... are much more likely to be selected as the foreperson.").

8. C. Hawkins, supra note 7, at 17.

9. Beckham \& Aronson, Selection of Jury Foremen as a Measure of the Social Status of Women, 43 Psychological Rep. 475, 476-77 (1978) (in 155 juries, women elected as foreperson one fifth as often as their number would indicate); Strodtbeck, James \& Hawkins, Social Status in Jury Deliberations, 22 AM. Soc. REv. 713, 715 (1957) [hereinafter Strodtbeck] ("only one-fifth as many women were made foreman as would be expected by chance"); C. Hawkins, supra note 7, at 24 (women constituted $36 \%$ of jurors, but only $3 \%$ of forepersons); see also R. HASTIE, S. PENRod \& N. PENNINGTON, INSIDE THE JURY 28 (1983) [hereinafter R. HAstie] ("[m]ales, higher classes, and end seating are overrepresented" in role of foreperson); R. SIMON, The JURY AND THE DEFENSE of INSANITY 114 (1967) (businessmen had four times better chance of being selected as foreperson than male laborers; housewives were never selected).

10. Even when women sit in the end position, both men and women are less likely to recognize them as leaders because of sex stereotypes of women as followers. Porter \& Geis, Women and Nonverbal Leadership Cues: When Seeing Is Not Believing, in Gender and Nonverbal BeHavior 53 (C. Mayo \& N. Henley eds. 1981); see also infra notes 20-24 and accompanying text (discussion of men's status in society and in jury room as contributing factor to their selection as foreperson).

11. The most recent studies support the results of earlier studies that the foreperson speaks more than any other juror. R. Simon, supra note 9, at 114-15 (mean participation rate of foreperson was 31.1\%, compared to 7.5\% for other jurors); Sannito \& Arnolds, Jury Siudy Results: The Factors at Work, 5 TRIAL DIPL. J. 6, 7 (1982) (From 550 completed juror questionnaires, 79\% of jurors described foreperson as either " 'talkative," " "one of the most talkative," " or " the most talkative" " compared to other jurors.); Strodtbeck, supra note 9, at 716 (foreperson was responsible for approximately one fourth of total acts).

12. R. HASIrE, supra note 9, at 145; C. Hawkins, supra note 7, at 26. Forepersons devoted a greater proportion of their statements to legal and organizational issues compared to other jurors and made fewer statements about their own verdict preference. In other areas, "their contributions were similar to those of other jurors, albeit more frequent." R. HASTIE, supra note 9, at 145. 
the points made by other jurors, ${ }^{13}$ the magnitude of difference in participation rates suggests that the foreperson contributed disproportionately to the jury deliberations. ${ }^{14}$

If the foreperson is excluded from the calculation, male jurors still have a higher participation rate than female jurors during the deliberation. Even adjusting for the difference in proportion of men and women, male jurors offered forty percent more comments than female jurors. ${ }^{15} \mathrm{Al}$ though the percentages differ slightly from study to study, the proposition that men participate at a significantly higher rate than women is well supported. ${ }^{16}$

Participation during deliberations is critical because the jury performs its task through the verbal communication of ideas. Those jurors who speak the most are viewed as the most persuasive by their peers. ${ }^{17} \mathrm{Men}$, who participate at a greater rate than women, are viewed by other jurors as having more influence and displaying greater leadership than women. ${ }^{18}$

13. When the foreperson is summarizing points raised by other jurors, he is still selecting which comments to emphasize, and consequently, exerting influence on the discussion.

14. R. HASTIF, supra note 9 , at 145 .

15. Id. at 141-42.

16. See, e.g., James, Status and Competence of Jurors, 64 AM. J. Soc. 563, 564 (1959) (average level of participation was $9 \%$ for male juror and $7 \%$ for female juror); Strodtbeck, supra note 9, at 715 (rate of participation was $9.6 \%$ for male jurors and $6.6 \%$ for female jurors); C. Hawkins, supra note 7 , at 34 (average participation level of white male was $7.9 \%$ and of white female was $6.1 \%$ ); see also Strodtbeck \& Mann, Sex Role Differentiation in Jury Deliberations, 19 SOcIOMETRY 3, 5 (1956) (male jurors initiate more discussion than female jurors in mock jury trials). But see R. Simon, supra note 9, at 115-16. Simon did not find a difference between men's and women's participation rates in her study. Both men and women had a mean participation rate of $7.5 \%$. Id. One of the cases, however, involved incest, and in crimes against children, women might speak more frequently. Id. at 116.

17. See R. HASTIE, supra note 9, at 145-46 (persuasive juror was likely to be educated male who participated frequently in deliberation); James, supra note 16, at 566-68 (jurors with highest participation rate or highest level of education were seen as most persuasive); Strodtbeck, supra note 9, at 715-16 (men participated at greater rate than women and were viewed by other jurors as more useful in deliberation process). But see R. Simon, supra note 9, at 119. According to Simon, men who spoke more did not wield more influence, defined as "the ability of the members of a minority faction to persuade the majority to their point of view," than those who spoke less.

18. See L. Smith \& L. Malandro, supra note $7, \S 4.48$, at 424 ("How much is said . . appears to be more important to the perception of leadership than what is said . . ."); Hollander, Women and Leadership, in 1 Small Groups and Social Interaction 425 (H. Blumberg, A. Hare, V. Kent \& M. Davies eds. 1983) ("Members who participate more are likely to be more influential and to be seen as leaders."); Regula \& Julian, The Impact of Quality and Frequency of Task Contributions on Perceived Ability, 89 J. Soc. Psychology 115, 120 (1973) (individual who contributes more frequently to discussion is perceived as more "able" than one who contributes less frequently); Sorrentino \& Boutillier, The Effect of Quantity and Quality of Verbal Interaction on Ratings of Leadership Ability, 11 J. ExPerimental Soc. Psychology 403, 408 (1975) ("quantity and not quality of verbal interaction is the better predictor of leadership").

According to another research team's findings, male mock jurors who participated at a higher rate than female mock jurors were perceived as more influential, active, and leader-like than the female mock jurors. Nemeth, Endicott \& Wachtler, From the '50s to the '70s: Women in Jury Deliberations, 39 Sociometrry 293, 299 (1976) [hereinafter Nemeth]. But in a second study, involving male and female mock jurors who participated at equal rates, the men were still perceived as more influential, active, and leader-like than the women. Id. at 300,302. Such data suggest that both gender and 
The sheer quantity of their comments gives weight to their content. ${ }^{19}$ The ideas of male jurors, then, receive more attention than those of their female counterparts.

The status that society at large assigns to men contributes to the difference in men's and women's participation rates in the jury room. ${ }^{20}$ When men and women enter the jury room, they do not leave behind the lessons that society teaches about appropriate behavior for men's and women's interaction. ${ }^{21}$ Power relations of male dominance and female subordination are manifested in the jury room through gender-related behavior. Such patterns of behavior are often difficult to detect because they are embedded in our society, but they nonetheless function to limit women's participation. For example, studies show that men speak more often, at greater length, and are more likely to interrupt other speakers than women. ${ }^{22}$ One effect of this male behavior is that women's silences

participation rates are factors in determining jurors' persuasiveness. The authors found that men and women, consistent with "the folklore of attorneys, tended to assume that women are relatively more passive, weak, and non-influential." Id. at 304 (emphasis added); see also Broverman, Vogel, Broverman, Clarkson \& Rosenkrantz, Sex-Role Stereotypes: A Current Appraisal, 28 J. Soc. Issues 59, 69 (1972) (college students, "a group which tends to be critical of traditional social norms and conventions," approved of sex-role stereotypes of women as less aggressive, dominant, active, and competent than men).

19. See Hoffman, Group Problem Solving, in Group Processes 73 (L. Berkowitz ed. 1978) ("he who talks the most is likely to promote his solution to the group successfully"); Bavelas, Hastorf, Gross \& Kite, Experiments on the Alteration of Group Structure, $1 \mathrm{~J}$. Experimental. Soc. PsYCHology 55, 59 (1965) [hereinafter Bavelas] (group members perceived those who spoke most often to offer best ideas and guidance).

20. One theory claims that the sex of an individual confers a certain status. Males have a higher status than females, and consequently, males are expected to make more contributions, to have more influence, and to receive more expressions of approval than females for whom there are lower performance expectations. See Meeker \& Weitzel-O'Neill, Sex Roles and Interpersonal Behavior in Task-Oriented Groups, 42 AM. Soc. REv. 91, 95 (1977). Such expectations would explain why men and women perceive men to be more influential and to display greater leadership than women even when men and women are participating at the same rate. See Nemeth, supra note 18, at 302-03.

According to Rosabeth Moss Kanter's theory, men and women may not be "peers" in mixed groups because of differences in status and power. She concludes that "[t]he resulting behavior, including frequency of participation, leadership, and conformity, may reflect status and power differences more than sex-linked personality traits." Kanter, Women and the Structure of Organizations: Explorations in Theory and Behavior, in ANOTHER VoICE 56 (M. Millman \& R. Kanter eds. 1975). Kanter also suggests that women in jury studies, as in corporations, may assume traditional roles because they are outnumbered by men and that male-female interaction will change when both sexes are equally represented. R. Kanter, Men and Women of the Corporation 208 (1977). One problem for the jury, however, is that the number of women and men on any given jury cannot be guaranteed.

21. For an account of how power relations define gender roles, see generally MacKinnon, Feminism, Marxism, Method, and the State: Toward Feminist Jurisprudence, 8 SIGNS: J. WOMEN GuLTURE \& SOC'y 635 (1983) ("Male and female are created through the erotization of dominance and submission. The man/woman difference and the dominance/submission dynamic define each other.").

22. N. Henley, Body Polrrics 74 (1977) (men speak more often than women in both singlesex and mixed-sex groups or pairs, as well as among experimentally created pairs or groups and actual husband-wife couples); Baird, Sex Differences in Group Communication: A Review of Relevant Research, 62 Q.J. SPEECH 179, 181 (1976) ("males used more words, talked more often, and, in mixed groups, interrupted females more frequently than females interrupted them"); West \& Zimmerman, Small Insults: A Study of Interruptions in Cross-Sex Conversations Between Unacquainted Persons, in Language, Gender and Society 107 (B. Thorne, C. Kramarae \& N. Henley eds. 
lengthen as men interrupt, overlap, or give a delayed or minimal response to the female speaker. ${ }^{23}$ One obvious way to maintain power in a group is to monopolize and control discussion. Those who have power can do the talking; those who lack power must do the listening. ${ }^{24}$

The power relations of male dominance and female subordination that structure our society also shape our legal institutions. As feminist writers have observed, the legal system neither operates neutrally toward, nor independently of, power relations in society. ${ }^{25}$ Legal institutions, including the jury, were structured by men for their protection and benefit. Not surprisingly, they preserve and reflect the power imbalance that occurs in society at large.

1983) (in cross-sex conversations, men are three times more likely than women to interrupt other speaker).

Nonverbal behavior, such as gesture, movement, touch, gaze, and spatial arrangements, also perpetuate gender differences in power and status:

The "trivia" of everyday life . . . touching others, dropping the eyes, smiling, interrupting, and so on . . . are commonly understood as facilitators of social intercourse, but are not recognized as defenders of the status quo-of the state, of the wealthy, of authority, of all those whose power may be challenged. Nevertheless, these minutiae find their place on a continuum of social control which extends from internalized socialization ... to sheer physical force .....

Henley, Power, Sex, and Nonverbal Communication, in Language and Sex 184 (B. Thorne \& N. Henley eds. 1975).

23. Zimmerman \& West, Sex Roles, Interruptions and Silences in Conversation, in Language AND SEx, supra note 22, at 118 (in cross-sex segments of conversation, $62 \%$ of females' aggregate silence followed after a male's delayed or minimal response, overlap, or interruption).

24. See Marcus, Spiegelman, DuBois, Dunlap, Gilligan, MacKinnon \& Menkel-Meadow, The 1984 James McCormick Mitchell Lecture: Feminist Discourse, Moral Values, and the Law-A Conversation, 34 Buffalo L. Rev. 11, 62 (1985). Carol Gilligan uses her examples of Amy and Jake to make the more general observation that "[i]f you have power, you can opt not to listen. And you do so with impunity." Id. at 62; see also note 46 (detailed discussion of Amy's and Jake's different modes of moral reasoning).

25. Our legal system reflects the male point of view because men, as the members of society with power, can structure the law to reflect and protect their needs. "The law sees and treats women the way men see and treat women." MacKinnon, supra note 21, at 644. MacKinnon argues that society's power relations-male dominance and female subordination-explain the legal system's current inability to respond to women's subjection to sexual harassment. See C. MacKinnon, Sexual. HaRASSMENT 158 (1979) ("Because sexual harassment . . . has appeared so much a part of the normal and expectable behavior between the sexes, the law has fallen short of women's needs and aspirations.").

The legal system, according to Tong, is "skewed in ways that favor men's interests and rights." $R$. TONG, WOMEN, SEx, AND THE LAw 205 (1984). It has long treated woman-battering as "a trivial or a largely imagined phenomenon, as a woman's deserved treatment rather than the criminal violation of her rights." Id. at 124. Although the victim can theoretically pursue remedies in criminal or tort law, these remedies are not always enforced by the state. See, e.g., Note, Battered Women and the Equal Protection Clause: Will the Constitution Help Them When the Police Won't?, 95 YALE L.J. 788 (1986) (failure of police to arrest battering husbands violates women's equal protection right and perpetuates men's domination over women). For another critique of the legal system as maledominated and male-structured, see Polan, Toward a Theory of Law and Patriarchy, in THE PoLrTICs of LAw 301 (D. Kairys ed. 1982) ("The whole structure of law-its hierarchical organization; its combative, adversarial format; and its undeviating bias in favor of rationality over all other values-defines it as a fundamentally patriarchal institution."). 


\section{The Necessity of Full Participation}

The jury performs several functions in American society. One of the jury's roles, and perhaps its least controversial role, is to serve as factfinder. ${ }^{28}$ Another role of the jury is to apply (or not to apply) the law to the facts; in this case the jury performs a law-making function. ${ }^{27}$ In addition, the jury plays an educational role: It teaches the citizenry about democracy and its concomitant responsibilities. ${ }^{28}$ All of these roles can best be served if women participate fully in jury deliberations.

\section{A. Improving the Accuracy of Jury Fact-Finding}

Women need to speak more and men need to listen more if the jury is to enjoy the benefits of "group" deliberation. ${ }^{29}$ Unless both men and women speak and are heard during the deliberations, the jury will consider and decide from only a limited view of the facts and evidence. In-

26. See, e.g., Broeder, The Functions of the Jury: Facts or Fictions?, 21 U. CHI. L. REv. 386, 387 (1954) ("The jury's central legal function is to resolve the factual disputes involved in a law suit."). Broeder, however, questions the jury's ability to perform this task. See id. at 390; see also Note, The Federal Jury Selection Act of 1968: A Critique, 2 Colum. Surv. Hum. RTs. L. 52, 54 (1969-1970) ("Three interrelated tasks [of the jury] are generally recognized: the jury's fact-finding function; its legislative function; and the 'good exercise in democracy' function.").

27. Scheflin \& Van Dyke, Jury Nullification: The Contours of a Controversy, 43 LAw \& CoNTEMP. PRORS., Autumn 1980, at 51, 68. To fulfill this task properly, a jury must be selected from a representative cross section of the community. Different segments of the community may have different perspectives and all of these perspectives should be heard. See Kershen, Vicinage, 30 OKLA. L. REv. 1, 83 (1977) ("Unless the jury applies the law to the facts so as to articulate the community sense of justice, there is justifiable fear that the jury will not feel responsibility for the verdict rendered. Unless the jury renders a verdict in which the community sense of justice is articulated, an accused may not feel that he has been judged, but rather may feel he has been processed."). It is not always easy to distinguish between the jury's functions of fact-finding and of applying law to fact. See, e.g., Broeder, supra note 26 , at 406.

28. See, e.g., Broeder, supra note 26 , at 419 ("Jury service furnishes the only means, other than by voting, through which the citizen can actually participate in the administration of government."); Kalven, The Dignity of the Civil Jury, 50 VA. L. Rev. 1055, 1062 (1964) ("T'T]he jury provides an important civic experience for the citizen. . . . The heart of the matter, the trial itself and the deliberation, is very often a major and moving experience in the life of the citizen-juror."); Kershen, supra note 27, at 83 (" $\mathrm{As}$ Thomas Jefferson stated, participation of the ordinary citizen on a jury permits a democratic element to be preserved in the administration of justice by the judicial branch of the government.").

29. See Ballew v. Georgia, 435 U.S. 223, 233 (1978) ("When individual and group decisionmaking were compared, it was seen that groups performed better because prejudices of individuals were frequently counterbalanced, and objectivity resulted."); Kalven, supra note 28, at 1067 ("Different jurors remember, and make available to all, different items of the trial so that the jury as a group remembers far more than most of its members could as individuals."); see also L. SMITH \& L. MALANDRO, supra note $7, \S 4.39$, at 409 ("group judgments are usually as good as and often superior to individual judgments"); Barnlund, A Comparative Study of Individual, Majority, and Group Judgment, 58 J. ABNORMal. \& Soc. Psychology 55 (1959) (in freshman course, least skilled problem solvers working in groups solved syllogisms as well as most skilled members working alone). The author explained that "[g]roup decisions, reached through cooperative deliberation, are significantly superior to decisions made by individual members working alone" because group discussion "was found to stimulate more careful thinking, to lead to a consideration of a wider range of ideas, and to provoke more objective and critical testing of conclusions." Id. at 59-60. This study, though done in 1959, was cited in 1978 by the Court in Ballew, 435 U.S. at 233 n.14. 
deed, as many studies demonstrate, the domination of a few and the silence of others increase the likelihood of erroneous group decisions. ${ }^{30}$ If those who are able to correct a mistaken view fail to speak, then the mistake will go uncorrected. In the case of the jury, an inaccurate decision can have devastating consequences, particularly when it results in the wrongful conviction of an innocent person. ${ }^{31}$

In Ballew v. Georgia ${ }^{32}$ the Supreme Court, citing empirical studies, ${ }^{33}$ pointed to the importance of memory in ensuring jury accuracy. ${ }^{34}$ As juries decrease in size, the number of jurors who might remember different pieces of evidence is reduced. Accordingly, the risk of convicting an innocent person increases. If women systematically choose not to speak or men choose not to listen when women do speak, then the jury is, in effect, reduced in size. Memory gaps in the group's collective knowledge increase.

In addition, if women participated fully in jury deliberations, they would contribute facts that female, rather than male, jurors are more likely to recall. Women are more likely to hear, see, or remember different facts than men, not because of some natural difference, but because women, in general, occupy a different place in society than men. ${ }^{36}$

30. See, e.g., Hoffman, supra note 19, at 68 (limited expression of ideas decreases chances that group will reach correct solution); Maier \& Solem, The Contribution of a Discussion Leader to the Quality of Group Thinking: The Effective Use of Minority Opinions, 5 Hum. ReL. 277, 285 (1952) ("free discussion tends to increase the number of correct answers to a problem for which a variety of incorrect answers seems plausible").

31. As the Supreme Court acknowledged, "[t]he vagaries of eyewitness identification are wellknown; the annals of criminal law are rife with instances of mistaken identification." United States $v$. Wade, 388 U.S. 218, 228 (1967); see, e.g., Campbell v. State, 186 Misc. 586, 62 N.Y.S.2d 638 (Ct. Cl. 1946) (upholding constitutionality of special law awarding damages to claimant for erroneous arrest, conviction, and confinement as result of mistaken identity); Hermann, The Case of the Jamaican Accent, N.Y. Times, Dec. 1, 1974, $\$ 6$ (Magazine), at 30 (erroneous eyewitness identification led to wrongful arrest of Ted Alston). See generally E. BorCHARD, Convicting THE INNOCENT (1932) (65 cases of wrongful convictions).

32. 435 U.S. 223 (1978).

33. Id. at 232-39 (empirical studies demonstrate that reducing jury size to five members adversely affects jury deliberations).

34. The Court in Ballew concluded that reducing the jury in a state criminal trial to five members would reduce the amount of evidence accurately recalled by and available to the jurors, hinder effective jury deliberations, increase the likelihood of erroneous decisions, weaken the minority's ability to defend its view, and decrease the representation of minorities on the jury. Id. at 232-38.

35. Professor Williams attributed this difference in perceptions to a difference in men's and women's respective life experiences. Williams, The Equality Crisis: Some Reflections on Culture, Courts, and Feminism, 7 Women's Rts. L. Rep. (Rutgers Univ.) 175 (1982).

For an illustration of women's and men's different perceptions and judgments as a result of their different positions in society, see Glaspell, A Jury of Her Peers, reprinted in THE BEST SHORT STORIES OF 1917, at 256-82 (E. O'Brien ed. 1918). In this short story, a neighbor who had been strangled in his sleep with a rope is discovered dead. His wife claims that she had been asleep beside him, but had not been awakened. The sheriff and another neighbor, accompanied by their wives, and the county attorney, go to the house to search for evidence. The men look in the bedroom and the barn and are unable to discover the wife's motive for the murder of her husband. The women remain in the kitchen where they focus on "the insignificance of kitchen things" and piece together the motive for the murder. Id. at 263. 
According to one study, men and women both pay more attention to and store more or better information about items that attract their interest. $^{36}$ For example, women recalled better information about a female victim's actions, whereas men responded more accurately about the male thief's appearance. ${ }^{37}$

One study has shown that although both men and women tend to overestimate witnesses' ability to identify a suspect, men do so more than women. ${ }^{38}$ Such a gender difference is significant because jurors give eyewitness testimony much more weight than other evidence. ${ }^{38}$ Because men on juries participate more than women, one would predict that jury decisions tend to overestimate eyewitness credibility. In fact, this is what studies have shown, though researchers have failed to note the causal relation. ${ }^{40}$ The jury's general tendency to accept the accuracy of eyewitness testimony could be challenged if women voiced their views as often as men did.

The men and women had the same evidence available to them, but they chose to focus on different items because of their different perceptions about the items' importance. As a result, the men and women arrived at different explanations for the crime. The story suggests not only that women see things differently than men, but also that they evaluate their discoveries differently because of their position in society. The women identified the murderer, but understood the circumstances that drove her to such action. They also recognized that a male court of law was unlikely to understand or sympathize with her circumstances. Weisbrod, Images of the Woman Juror, 9 HARv. WoMEN's L.J. 59,76 (1986). The differences in perception and judgment suggested by this story are rot immutable, however, and will change as women's status and position in society change.

36. E. Lofrus, Eyewrtness Trstimony 157 (1979); see also A. Yarmey, The Psychology of Eyrwitness TEstimony 91 (1979) (men and women differ in their observations of others); Powers, Andriks \& Loftus, Eyewitness Accounts of Females and Males, 64 J. APPLIED Psychology 339 (1979) (women were more accurate in their recollection of female-oriented items whereas men were more accurate in their recollection of male-oriented items).

37. E. Lofius, supra note 36 , at 157.

38. Brigham \& Bothwell, The Ability of Prospective Jurors To Estimate the Accuracy of Eyewitness Identifications, 7 LAw \& HUM. BeHAv. 19, 26-27 (1983) (subjects asked to estimate how many witnesses correctly identified suspect in line-up). One possible explanation for this difference in perception is that women are accustomed to seeing the world from a multiplicity of perspectives. They are confronted with a "conflict between their own perceptions and often prevailing views of 'truth' or 'history.' " Letter from Professor Martha Minow, Harvard Law School, to author (Mar. 1, 1986). As a result, they may be less accustomed to finding that "reality" is identical to their perceptions of reality and may have less confidence than men that others can find such a correspondence. See infra note 46 (discussion of women's tendency to accommodate several points of view, rather than to impose single point of view).

39. E. Lofius, supra note 36, at 10. Loftus identifies many factors, such as stereotypes, past experience, prejudice, temporary expectations, stress, weapon focus, cross-racial identification, and transference, to try to convince readers (and jurors) that eyewitness testimony is unreliable and should be given less weight. Id. at 33-51; see also Buckhout, Eyewitness Testimony, ScI. AM., Dec. 1974, at 23 (describing factors that contribute to unreliability of eyewitness testimony).

40. See E. Lofrus, supra note 36, at 10; see also Brigham \& Bothwell, supra note 38, at 27 (jurors find eyewitness evidence extremely persuasive). Although researchers have noted that there is "some evidence of a sex effect" between males' and females' assessment of eyewitness credibility, id. at 27 , they have failed to connect the jury's tendency to overestimate eyewitness credibility with the male jurors' tendency to dominate discussion. 


\section{B. Improving the Effectiveness of the Deliberation Process}

Women influence the interaction process that determines the group's effectiveness in recalling different facts and in reaching an accurate verdict. In one study of mock jury deliberations, the researchers identified two contrasting deliberation styles. ${ }^{41}$ A "verdict-driven" deliberation is one that begins with a public ballot and is dominated by statements of verdict preference. Individual jurors adopt one position and cite evidence only in support of that position. In contrast, in "evidence-driven" deliberations, public balloting occurs late in the process, and the group emphasizes story construction. Individual jurors offer evidence without reference to a particular verdict, as they try to recreate the events at the time of the alleged crime.

Research in organizational behavior shows that evidence-driven discussions lead to better interaction, and consequently, to more accurate decisions than verdict-driven discussions. ${ }^{42}$ Verdict-driven discussion creates adversarial factions preoccupied with winning the point and silencing the dissenters. ${ }^{43}$ Verdict-driven deliberations also involve fewer participants; each side, rather than every individual, articulates its view. Because both sides are often unwilling to relent, verdict-driven deliberations are more likely to result in hung juries. ${ }^{44}$ Evidence-driven discussion relies upon open communication so that all members feel that they have had a fair chance to influence the decision. ${ }^{45}$ Those who have a different recollection of the facts or who hold a minority opinion in the group speak because others are willing to listen and to consider what they are saying.

41. R. HASTIE, supra note 9, at 163-65. In an earlier work, Hawkins also identified two styles of jury deliberation: "deliberating in unity" and "deliberating in factions." C. Hawkins, supra note 7, at 106-09. Jurors deliberating in the former style presented arguments without being associated with any particular verdict preference. Jurors deliberating in the latter style expressed their personal preference and then aligned with others who shared that viewpoint. Hawkins hypothesized that juries "deliberating in unity" would reach "better" decisions than those "deliberating in factions": "A group which tries to reach a decision without dividing into factions does not pay any attention to how the people are lined up but only to how the weight of rational argument is lined up . . . " Id. at 115.

42. Although R. HASTIE, supra note 9, at 163, used these terms, other studies in organizational behavior recognize these two modes of discussion under different names. These studies also suggest that the evidence-driven mode is more effective in producing accurate decisions or solutions. See, e.g., Hoffman, supra note 19, at 82 ("[E]valuat[ing] suggested solutions as they appear, instead of waiting until all suggestions are in and then making [a] choice . . may promote a mediocre solution or it may kill off a good one early.").

43. One organizational behavior study uses the terms "Decision by Majority Rule: Voting and/or Polling" and "Decision by Consensus." E. Schein, Process Consultation: Its Role in Organization Development 55-56 (1969). According to Schein, the danger in decision by "Voting and/or Polling" is that voting creates coalitions, which then focus on winning the battle. The minority members may feel that they have insufficient opportunity to convince others of their point of view. Id. at 56.

44. See R. HASTIE, supra note 9, at 165-67; C. Hawkins, supra note 7, at 81 .

45. E. SCHEIN, supra note 43 , at $56-57$. A disadvantage of this mode of deliberation is that it is time-consuming. 
As studies have shown, women in general express more concern than men about accommodating different points of view among members of a group and translate that concern into an evidence-driven mode of discussion. ${ }^{46}$ In studies of all-female groups, the more active speakers tried to draw out the more silent members, which is a key characteristic of evidence-driven juries. In contrast, in all-male groups, the more active members eventually ignored the less active members, which is a key characteristic of verdict-driven juries. ${ }^{47}$ The men displayed competitiveness with other men, whereas the women expressed cooperation with other women. ${ }^{48}$ In mixed groups, however, the women consistently became more silent. ${ }^{49}$ If women are encouraged to speak more and men are reminded to

46. See Bond \& Vinacke, Coalitions in Mixed-Sex Triads, 24 Socrometry 61, 72-73 (1961) (in game situations, males adopt "exploitative" or competitive strategy, whereas females adopt more successful "accommodative" or social relations strategy); Denmark, Styles of Leadership, 2 PsychoLOGY WOMEN Q. 99, 110-11 (1977) ("The one difference investigators generally agree upon is women's greater concern for relationships among people; this should be considered a plus in terms of leadership effectiveness.").

For a theory of differences between men's and women's approaches to moral reasoning, see C. Git.i.IGAN, In a Different Voick: 24-63 (1982). Gilligan describes two modes of moral reasoning, care-based and rights-based, and finds from her studies that women tend to adopt the former and men the latter. She clarifies the distinction between the two modes by using the examples of Amy and Jake, both of whom are asked to respond to Heinz's dilemma. Heinz's wife is dying, but because of his penury he cannot afford the drug that will save her life, unless he is willing to steal it from the pharmacist. Jake is willing to establish a hierarchy in which the conflicting rights of the pharmacist and Heinz can be placed, whereas Amy is reluctant to impose such a hierarchy. Instead, she strives to redefine the dilemma so that she no longer has to choose among the rights of the parties, but can arrive at a solution that meets all of the parties' needs. See id. at 25-32. For a theory of the origin of gender differences, see N. Chodorow, The Reproduction of Mothering 167 (1978) (girls emerge from mother-child relationship with "stronger basis for experiencing another's needs or feelings as one's own"); for a vision of what legal institutions would look like if informed by women's values and approaches, as first suggested by Gilligan, see Menkel-Meadow, Portia in a Different Voice: Speculations on a Woman's Lawyering Process, 1 Berkeley Women's L.J. 39 (1985) (suggesting that female lawyers can shape their profession by searching for solutions that encompass both parties' needs rather than adopting traditional adversarial model, in which one party wins and other loses).

47. Aries, Male-Female Interpersonal Styles in All Male, All Female and Mixed Groups, in BEyond SEX Roles 294 (A. Sargent ed. 1977). In all-male groups, those who missed a session became inactive speakers upon rejoining the group and were subsequently unable to assume important positions in the group. In contrast, in all-female groups, those who missed a session were encouraged to play a more active role in the group during the following session. See also Baird, supra note 22, at 189-90 (in all-male groups, weakest member is excluded; in all-female groups, any member in danger of neglect is given encouragement).

48. Aries, Interaction Patterns and Themes of Male, Female, and Mixed Groups, 7 Small Group BEHAv. 7, 13-14 (1976). Discussions in all-male groups were marked by competition and aggression. The theme of victim and victimizer recurred in anecdotes about pranks, jokes, and clubs. In contrast, discussions in all-female groups centered on feelings, affiliation, home, and family. See Reed, Gender Issues in Training Group Leaders, J. SPEcialists Group Work, Aug. 1981, at 161, 162 (all-male groups characterized by hierarchy and competition; all-female groups shared feelings and discussed subjects in greater depth).

49. Aries, supra note 47 , at 297 (in mixed groups, women spoke less, initiating only $34 \%$ of total interaction); Reed, supra note 48 , at 163 (in mixed groups, women spoke less, spoke primarily to men, shared less personal information, and were less involved in topics and tasks associated with masculinity). 
listen more, ${ }^{80}$ women may be able to bring to jury deliberations their tendency to engage in evidence-driven discussion, which produces more accurate decisions.

\section{Broadening the Range of Perspectives Available to the Jury}

Gender, like age and race, informs one's relations with others and one's experiences and position in society. ${ }^{51}$ Thus, the two genders have different perspectives to contribute when determining facts and applying law to facts. The use of juries is predicated on the assumption that different people see things differently, and one function of the jury is to bring people's different perceptions to the trial process. ${ }^{52}$ Indeed, in Taylor $v$. Louisi$a n a^{53}$ and Duren v. Missouri ${ }^{54}$ the Supreme Court recognized the importance of juries composed of a cross section of the population, representing, and presumably articulating, a broad spectrum of views. The Court reiterated in Ballew that the jury is often called upon to make difficult value choices, and therefore, needs to draw upon "the sense of the entire community" to make such decisions. ${ }^{\mathrm{sb}}$

50. Effective change in group dynamics requires the awareness and responsiveness of both quiet and talkative members of the group: "[W]ithout some encouragement a quiet group member will not spontaneously increase his output when other members are artificially depressed; and conversely it is not enough to encourage a quiet individual to participate more unless 'room' is provided for his increased output." Bavelas, supra note 19 , at 67.

51. See Alderfer, An Intergroup Perspective on Group Dynamics, in Handbook of OrganizaTIONAL. BFHAVIOR 219 (J. Lorsch ed., forthcoming).

Many feminist scholars argue that one's perspective is informed by one's gender; there is no "ungendered perspective": To believe in a universal, objective standpoint is to accept the male point of view. MacKinnon, supra note 21, at 636; see also C. GiLligAN, supra note 46, at 2 ("differences arise in a social context where factors of social status and power combine with reproductive biology to shape the experience of males and females"); R. TONG, supra note 25, at 200 ("differences of perspective between men and women . . . stem primarily from socially created and maintained inequalities of knowledge and power"). Because these differences in perspective are socially created, they can change over time depending upon changes in the status and power of women.

Some scholars argue that gender should not inform perspective. See, e.g., Wasserstrom, Racism, Sexism, and Preferential Treatment: An Approach to the Topics, 24 UCLA L. REv. 581, 606 (1977) (ideal society would follow assimilationist model of no differences between men and women: "It would never teach about the inevitable or essential attributes of masculinity or femininity. . . . Were sex like eye color, these things would make no sense."). Of course, the politics of either position has its pitfalls: To overlook the inequalities that exist may be to accept oppression; to recognize the reality of inequalities may be to perpetuate denigrating stereotypes. Law, Rethinking Sex and the Constitution, 132 U. PA. L. Rkv. 955, 965 n.29 (1984).

52. See Zeisel, . . . And Then There Were None: The Diminution of the Federal Jury, $38 \mathrm{U}$. CHI. L. REv. 710, 715 (1971); see also Scheflin \& Van Dyke, supra note 27, at 68 ("Jurors bring a variety of perspectives to their deliberations that enables them to see beyond the single viewpoint of the judge.").

53. 419 U.S. 522 (1975) (Louisiana statute requiring voluntary registration by potential female jurors held to violate criminal defendant's Sixth Amendment right to trial by impartial jury drawn from "a fair cross section of the community").

54. 439 U.S. 357, 363-64 (1979) ("fair-cross-section" Sixth Amendment claim requires showing of disproportionality among distinctive groups in community arising from systematic exclusion of group in jury selection process).

55. Ballew v. Georgia, 435 U.S. 233, 241 (1978). 
Gender-related perspectives have their strongest manifestation in rape or death penalty cases. Obviously, no individual is confined to any one perspective strictly because of gender; people's perspectives are genderrelated, not gender-specific. ${ }^{88}$ Empirical studies, however, report differences in male and female jurors' attitudes on these subjects, and it is important that such different viewpoints are articulated during the deliberations. Differences in attitudes toward rape and the death penalty appear to be "the most powerful individual difference predictors" of verdict preferences that researchers have studied to date. ${ }^{57}$

According to empirical studies involving rape cases, female jurors are more likely than male jurors to convict the defendant and to assign him a longer sentence. ${ }^{58}$ One study found that female jurors were less influenced by the rape victim's virginity or social status and were more likely to assign the defendant a longer prison term than their male counterparts. ${ }^{59}$

Death penalty cases also seem to elicit a difference in attitudes between men and women. Several studies have concluded that women are more likely than men to oppose the death penalty, and consequently, to be excluded from "death-qualified" juries. ${ }^{80}$ Such exclusion limits the range of

56. Gilligan, Remapping Development: The Power of Divergent Data 11 (Jan. 1984) (unpublished manuscript available in Yale Law School Library). Gilligan emphasizes that her discussion of gender differences assumes that the observed differences do not apply to all men or all women (they are not "gender-specific"), but that there is simply a discernible association or pattern (they are "gender-related").

57. R. Hasrtk, supra note 9, at 128. In any discussion of differences in attitude between men and women, it is important to remember that views change during the deliberation process as jurors' own biases are exposed, and as jurors are exposed to others' views. However, a range of views should be represented on the jury, and articulated during deliberations, so that the jury can consider as broad a spectrum as possible.

58. See Jacobson, Effects of Victim's and Defendant's Physical Attractiveness on Subjects' Judgments in a Rape Case, 7 Sex Roles 247, 252-53 (1981) (women less likely than men to believe or sympathize with alleged rapist, more likely to find him guilty, and to recommend longer prison sentence). For other studies that report differences between male and female responses to rape cases, see Calhoun, Selby \& Warring, Social Perception of the Victim's Causal Role in Rape: An Exploratory Examination of Four Factors, 29 HuM. ReL. 517, 523 (1976) (male subjects believed victim contributed to rape to significantly greater degree than female subjects); Davis, Kerr, Atkin, Holt \& Meek, The Decision Processes of 6- and 12-Person Mock Juries Assigned Unanimous and Two-Thirds Majority Rules, 32 J. Personality \& Soc. Psychology 1, 6 (1975) (male subjects generally judged rape to be more difficult to commit than female subjects); Rumsey \& Rumsey, A Case of Rape: Sentencing Judgments of Males and Females, 41 Psychological ReP. 459, 464 (1977) (when evidence of rape was ambiguous, male subjects were more likely than female subjects to blame victim).

59. S. Hoffman \& T. Dodd, Attribution of Responsibility to an Accused Rapist as a Function of Characteristics of the Victim and of the Subject 6-7 (unpublished manuscript), cited in Mahoney, Sexism in Voir Dire: The Use of Sex Stereotypes in Jury Selection, in WOMEN IN THE CourTs 126 (W. Hepperle \& L. Crites eds. 1978).

60. See Cowan, Thompson \& Ellsworth, The Effects of Death Qualification on Jurors' Predisposition To Convict and on the Quality of Deliberation, 8 LAW \& HuM. BEHAv. 53, 67 (1984) (potential jurors excluded from death-qualified juries more likely to be women); Fitzgerald \& Ellsworth, Due Process vs. Crime Control: Death Qualification and Jury Attitudes, 8 LAw \& Hum. BeHAv. 31, 46 (1984) (death-qualified juries exclude women and blacks). A "death-qualified" jury is one in which those who say that they could not vote for the death penalty in any case are excluded from the jury. 
views that will be expressed and considered during the deliberations and skews the range of community values represented on the jury. Empirical studies show that death-qualified juries tend to be less critical of the prosecutor's evidence and less concerned about due process guarantees than "mixed" juries, consisting of jurors who oppose and jurors who accept the death penalty. ${ }^{61}$

\section{Improving the Education of the Citizenry}

Jurors receive an education in democracy through full participation in a democratic institution such as the jury. ${ }^{62}$ According to Tocqueville, the jury serves as a "free school" to teach its citizens about the rights that democracy entails. ${ }^{\text {Bs }}$ More recently, one commentator observed that jury duty is the only governmental function in which citizens still play a direct role. ${ }^{64}$

When women first sought the right to jury duty, they argued that such service would enlighten women about the judiciary and the responsibilities of citizenship. ${ }^{65}$ If women today leave the jury room having learned that their opinions are not as important as those of their male peers, then they learn a harmful lesson. ${ }^{68}$ Women learn that they are not full citizens and, in addition, men learn that they need not respect the rights of others. Moreover, women will have lost the opportunity provided by their jury duty to be active citizens with influence in the judicial process.

\section{Steps To Allow for Full Participation}

A judicial understanding of the gender dynamics underlying small group interactions should improve jury deliberations. Courts must recognize the importance of group dynamics in jury deliberations and must take steps to educate jurors about behavior that promotes effective deliberations. ${ }^{67}$ Effective deliberations are critical if the jury is to reach accurate

61. Cowan, Thompson \& Ellsworth, supra note 60 , at $72-73,75-76$ (mixed jury is more critical of prosecution's evidence and more accurate in its recollection of facts of case than death-qualified jury); Fitzgerald \& Ellsworth, supra note 60 , at 42-43, 46, 48 (those excluded from death-qualified jury were more likely to be concerned about due process guarantees than those accepted).

62. See supra note 28.

63. A. DE Tocoueville, Democracy in America 275 (J. Mayer rev. ed. 1969) (13th ed. 1850).

64. Clark, The American Jury: A Justification, in Selected Readings: The JURY 1, 7 (G. Winters ed. 1971).

65. See, e.g., Sawyer, Women as Jurors, 15 AM. MERCuRy 139, 144 (1928) (jury duty will give women "a new conception of government and of their rights and privileges, as well as of their duties and responsibilities under it").

66. Gilligan emphasizes that jury duty also will teach a harmful lesson if "women experience themselves in a situation where they're unable to speak." Interview with Carol Gilligan, Associate Professor of Education, Harvard University, at Yale Law School (Feb. 18, 1986).

67. Ideally, the lessons of gender dynamics would be taught not only to jurors in the courtroom, 
verdicts. Of course, such education provides only a first step in making jurors aware of their behavior. But if the court teaches jurors about gender dynamics, just as it educates jurors about their other duties, then jurors are likely to take the lesson seriously, just as they try to adhere to the other instructions they receive. ${ }^{68}$

From the moment jurors enter the court, they should be taught about the effects of gender dynamics on their deliberations. They must be made aware, throughout the entire process, of the need for women to speak and for men to listen, so that both genders are participating equally. This message can be conveyed in straightforward and gender-neutral language through the variety of mediums the court already uses to educate jurors about their duties.

The courts can use the handbook ${ }^{69}$ that is currently sent to jurors in the mail or issued upon arrival to begin teaching jurors about the effects of gender dynamics. Currently, many handbooks include a section on juror behavior, in which jurors are advised to show consideration to their fellow jurors. ${ }^{70}$ This section should be expanded to include a discussion of the need for men and women both to speak and to listen to what others have to say. The handbook also should urge jurors to refrain from interrupting others or dominating discussion. ${ }^{71}$ Such a revision of the federal courts' handbook would be particularly timely, since the reference to juror behavior in the handbook has not been updated in over twenty-five years. ${ }^{72}$

but also to children in the classroom.

68. Jurors will take the judge's instructions seriously because they want to perform their job well.

As Kalven pointed out:

[T]here is much evidence that most people, once actually serving in a trial, become highly serious and resporsible toward their task and toward the joint effort to deliberate through to a verdict. Whether they are good at the job may be open to question, but that they are serious about it and give it a real try is abundantly documentable.

Kalven, supra note 28 , at 1062.

69. See, e.g., Anministrative Office of U.S. Courts, Handbook for Jurors Serving in THE UNITEd States District CoURT (1975) [hereinafter HaNDBOOK FOR JuRORS] (current handbook). According to one survey of types of juror orientation provided by state courts, of 131 judicial districts drawn from all 50 states, $64.1 \%$ provided a juror handbook. Forston, Sense and Non-Sense: Jury Trial Communication, 1975 B.Y.U. L. REv. 601, 624. However, the limitation of any handbook is that it is given to the potential juror at the beginning of the process. The uncertainty of selection may lead the potential juror merely to glance at, rather than to study, the handbook. Moreover, because it is so early in the process, the message bears repeating at other points throughout the court proceeding.

70. See, e.g., HANDBOOK FOR JURORS, supra note 69, at 11 ("The jurors have a duty to give full consideration to the opinion [sic] of their fellow jurors.").

71. The federal courts should revise their juror handbook to include a section on group dynamics. The handbook of Massachusetts state courts is one model insofar as it suggests the dynamics for which the jury should strive: "No juror should dominate the discussion. No juror should remain quiet and leave the speaking to others. Everyone should participate." OFFICE OF JURY COMM'R FOR THE Commonwealth, Trial. JuRor's Handbook 21 (1984).

72. The 1975 HANDBOOK FOR JURORs, supra note 69 , which is currently being distributed, has the same text in the relevant section as the 1959 handbook: "The jurors have a duty to give full consideration to the opinion [sic] of their fellow jurors." ADMIN. OfFICE of THE U.S. CourtS, 
Similarly, the videotape ${ }^{73}$ that introduces the jurors to the court and the legal process also should include a segment on effective deliberation methods. ${ }^{74}$ One videotape, for example, reminded the jurors that even though the jury experience might be new to them, they should all feel confident participating because they had all had experiences working in groups, whether in a boardroom, church group, or P.T.A. meeting. ${ }^{75}$ Ideally, the handbook and videotape should be coordinated so that each medium reinforces the message of the other. ${ }^{78}$ In those courts where the judge gives an introductory talk to the jurors, ${ }^{77}$ she also can offer a few comments on how an awareness of group dynamics can lead to fuller participation by all jurors, greater juror satisfaction with the process, and fairer decisions for the plaintiff and defendant. ${ }^{\text {78 }}$

The voir dire is another opportunity for the judge or lawyers to educate the jurors. ${ }^{79}$ Currently, it is common for judges, and for lawyers in some

Handbook for Jurors Serving in the United States District Court 11 (1959). A random survey of federal district courts' jury handbooks revealed use of the same handbook by all, although Maine is currently using the 1959 edition.

73. See, e.g., Juror Orientation (Massachusetts Jury Management Advisory Committee 1978) [hereinafter Juror Orientation] (videotape introducing jurors to courtroom procedures and several legal concepts); The Jury: Those Who Serve (Mikan \& Fleming 1979) [hereinafter The Jury: Those Who Serve] (film used in New Haven Superior Court to acquaint jurors with jury duty).

74. The videotape could include a segment on which behaviors to avoid, such as jurors interrupting each other, denigrating each other's ideas, or failing to allow the more reticent members to speak. The Massachusetts videotape, Juror Orientation, supra note 73 , repeats the advice given in the handbook, supra note 71 . Chief Justice James Lynch is the only speaker on this videotape. The message about gender dynamics could be conveyed more effectively if the Massachusetts videotape used dramatization rather than lecture.

The New Haven film, The Jury: Those Who Serve, supra note 73, provides a more lively presentation than the Massachusetts videotape. It is in color rather than black-and-white, uses people and dramatization to convey its message, and shows both men and women as judges and lawyers. Unfortunately, it pays scant attention to the deliberations in general and ignores the subject of participation completely. The film stresses the need for impartiality and admonishes jurors to "put aside all personal prejudices and sympathies," but does not offer advice about jurors' behavior toward each other. Id. About foreperson selection, the film says only that "at some point in time one of the jurors will have been selected foreman," and shows a male foreperson in a jury consisting of nine female jurors and only three male jurors. Id. About deliberations, the film says only that "there will be debating, some argument, and much talking." Id. A brief shot of two male jurors talking to each other completes the coverage of the deliberations. The New Haven film should give suggestions about behaviors to encourage and avoid during deliberations and should offer role models for women, such as a female foreperson and female jurors engaged in discussion. It should seek to educate jurors about the deliberations, just as it tries to teach them about other procedures such as voir dire.

75. Juror Orientation, supra note 73.

76. See Forston, supra note 69 , at 627 ("[T]here is a need to coordinate the various training procedures into a single orientation program. . . One innovative way . . . would be to produce an orientation film designed to be used in conjunction with a thorough, but readable, juror handbook.").

77. According to one survey, covering 131 different judicial districts drawn from all 50 states, state court judges in $82.4 \%$ of the districts examined still gave some introductory remarks or orientation to the jurors. $I d$. at 624 .

78. Strodtbeck found that the level of an individual's satisfaction with her jury duty was positively correlated with the level of her participation. Strodtbeck, supra note 9, at 716.

79. Many trial lawyers use voir dire as an opportunity to educate jurors about the meaning of certain instructions and about their duties during the trial and deliberations. Severance \& Loftus, Improving the Ability of Jurors To Comprehend and Apply Criminal Jury Instructions, 17 LAW \& 
jurisdictions, ${ }^{80}$ to remind jurors about what they have read in pamphlets or seen in videotapes about jury duty. In that context, the jurors could be reminded about what they have read and seen on gender dynamics and group deliberations. ${ }^{81}$ Just as potential jurors are questioned about their willingness to uphold the law, they could be questioned about their willingness to speak during deliberations, to listen to others, and to encourage others to speak and to listen. ${ }^{\mathbf{8 2}}$

In jurisdictions where the judge selects the foreperson, she should make sure that women are well represented over time. ${ }^{83} \mathrm{~A}$ female foreperson promotes greater awareness of gender dynamics. ${ }^{84}$ The presence of a female leader challenges stereotypes about women as followers and men as leaders. $^{80} \mathrm{~A}$ female leader also serves as a role model, thus creating a

Soc'y Rkv. 153, 173 n.20 (1982). Judge Craig reports that during voir dire he includes "an eighth grade civics lesson on how the court works," as well as a discussion of the indictment, of the statute on which the indictment is based, and an explanation of the burden of proof. Craig, Erickson, Friesen \& Maxwell, Voir Dire: Criticism and Comment, 47 Denver L.J. 465, 483 (1970).

80. According to one survey, based on 420 completed questionnaires, approximately three fourths of federal district judges conduct the voir dire without oral participation of the attorneys. G. Bermant, Conductr of the Volr Dire Examination: Practices and Opinions of Federal District Judgis 6 (1977). According to another study, 53.4\% of federal courts allow only the judge to conduct voir dire in criminal cases; $31.1 \%$ allow the attorneys to submit supplemental questions; $13.2 \%$ allow the attorneys to ask all of the questions; and $2.3 \%$ allow the attorneys or clerks to ask questions outside the presence of the court. WORKS OF THE COMM. ON THE OPERATION OF THE Jury Sys. of the Judicial. Conference of the U.S., The Jury System in the Federal CourTs 174 (1973). The trend is toward the judge-conducted voir dire. Ashby, Juror Selection and the Sixth Amendment Right to an Impartial Jury, 11 CREIGHTON L. REv. 1137, 1158 (1978). The federal rules of civil and criminal procedure give federal courts discretion about whether they allow attorneys to conduct the entire voir dire or merely to supplement questions asked by the court. See FED. R. Civ. P. 47(a); FED. R. CRIM. P. 24(a).

81. 1 E. Devitt \& C. Blackmar, Federal Jury Practice and Instructions $§ 3.01$ (2d ed. 1970) (judge has wide discretion in questioning potential jurors during voir dire).

82. In the past, lawyers have used voir dire to uncover racist attitudes among prospective jurors that could prevent them from applying the law. Van Dyke, Voir Dire: How Should It Be Conducted To Ensure That Our Juries Are Representative and Impartial?, 3 Hastings CoNST. L.Q. 65, 65-67, 92-94 (1976); see, e.g., Minimizing RAcism IN JURy Trials (A. Ginger ed. 1969). Similarly, voir dire can be used to expose sex-based biases. Soler, "A Woman's Place . . ": Combating Sex-Based Prejudices in Jury Trials Through Voir Dire, 15 Santa Clara LAw. 535, 568-71 (1975). Soler suggests questions, such as: "Do you think that women are as observant about details as men?" or "Do you feel that women should not be aggressive?" Id. at 586, 588. Such questions encourage jurors to examine their own attitudes on difficult issues. Lawyers could use voir dire to make jurors aware of the effects of gender dynamics. Lawyers might ask of a seemingly shy juror: "If you are selected as a juror, would you be willing to voice your opinions during deliberations?" or of a seemingly talkative juror: "If you are selected as a juror, would you pay careful attention to what others have to say and make sure to give others a chance to speak?" Lawyers would have to frame their questions so as not to offend, just as they must take care when questioning those who hold racist views and those who have been victims of racism.

83. See 1975 HANDBOOK FOR JURORS, supra note 69 , at 11 ("In some districts the judge selects the foreman of the jury."). Massachusetts is one state in which the judge selects the foreperson. Juror Orientation, supra note 73.

84. See Reed, supra note 48, at 166-67 (in groups with women leaders, members learn more about group dynamics and gender roles than in groups with male leaders).

85. Id.; see also Bartol \& Wortman, Male Versus Female Leaders: Effects on Perceived Leader Behavior and Satisfaction in a Hospital, 28 Personnel. Psycholocy 533, 544 (1975) ("[G]eneral surveys [indicate] that actual experience working for female supervisors tends to reduce negative atti- 
setting in which other women do become more outspoken and assertive. ${ }^{86}$ In addition, a female foreperson is more likely than a male foreperson to be concerned about the group's interaction and the need for all to speak and to be heard. ${ }^{87}$

The practice of requiring a jury to have a foreperson is a way in which the court helps to structure the jury deliberations. Whether the judge selects the foreperson or not, she should charge the foreperson to involve those who are silent and restrain those who are dominating. ${ }^{88}$ The judge should instruct the jurors, in language that is clear and free of jargon, on their role in assisting the foreperson to carry out her duties. ${ }^{89}$ The jury's

tudes toward females as leaders."). But see Mayes, Women in Positions of Authority: A Case Study of Changing Sex Roles, 4 Signs: J. Women Culrure \& Soc'y 556, 561 (1979) ("Males in the femaleled groups regularly expressed a fear of having lost control."). Because the selection of female forepersons challenges stereotypes of men as leaders, male jurors may resist female leadership and be uncooperative during deliberations. One antidote may be the jurors' respect for an authority figure, the judge. Note, Toward Principles of Jury Equity, 83 YALE L.J. 1023, 1049 (1974) (jurors may rely on judge's instructions about proper behavior in same manner as subjects trust experimenter's judgments about appropriate behavior); see also infra note 90 .

Although challenging stereotypes may present a risk, allowing stereotypes to go unchallenged also has its drawbacks. At the very least, women's opinions will remain unheard and their leadership skills under-utilized. See, e.g., Eskilson \& Wiley, Sex Composition and Leadership in Small Groups, 39 SOcIOMETRY 183, 192 (1976) (in completion of group task, groups performed equally well under male and female leadership, but female leaders were significantly less likely than male leaders to choose themselves as future leaders); Megargee, Influence of Sex Roles on the Manifestation of Leadership, 53 J. APplied Psychology 377, 378-81 (1969) (women who exhibit leadership qualities still reluctant to exert leadership over male partners). One illustration of this loss of female leadership was in the Harrisburg conspiracy trial. The defense attorneys recognized that Harold Sheets, a high status, authoritative, fact-minded man was a strong candidate for foreperson of the jury. At the same time, they recognized that another juror, $P$ at Schafer, was well-liked and respected and would have been elected foreperson "if the jurors were not so accustomed to male authority." Schulman, Shaver, Colman, Emrich \& Christie, supra note 1, at 81.

86. See Mayes, supra note 85 , at 560 (In female-led groups, women tended "to be more outspoken, assertive, and dominant in the conversation. As each meeting began, a woman spoke first, contrary to patterns observed in small-group studies of male-led or leaderless groups.").

87. See supra notes 46-50 and accompanying text; see also Wexley \& Hunt, Male and Female Leaders: Comparison of Performance and Behavior Patterns, 35 PsychologiCAL. REP. 867, 871 (1974) (female leaders exhibited more accommodative behaviors, such as agreeing more often, giving more opinions, and asking for more suggestions, than did male leaders); Goleman, Studies Point to Power of Nonverbal Signals, N.Y. Times, Apr. 8, 1986, at C1, col. 1 (women demonstrate greater awareness than men of others' nonverbal cues).

88. If the foreperson makes a special effort to elicit the expression of all minority viewpoints (not just those of women), then the jury will be more likely to avoid the dangers of "groupthink," in which group members conform to the prevalent view and effectively limit the range of ideas expressed and considered by the group. See I. JANIS, Groupthink 262, 270-71 (2d ed. 1982).

89. Many researchers have noted the incomprehensibility of jury instructions as a hindrance to proper jury performance. In one study, jury instructions were tested by actual deliberating jurors and troublesome sections were rewritten to ensure comprehension. Severance \& Loftus, supra note 79, at 161-62. Another study reported that all jury studies to date with the exception of one had found that the "legalese" of jury instructions had hindered jurors' efforts to understand and apply the instructions properly. Forston, supra note 69, at 617; see also Charrow \& Charrow, Making Legal Language Understandable: A Psycholinguistic Study of Jury Instructions, 79 Col.um. L. Rev. 1306 (1979) (jury instructions are made difficult by awkward grammatical constructions); Meyer \& Rosenberg, Questions Juries Ask: Untapped Springs of Insight, 55 JuDICATuRE 105 (1971) (questions arising from ambiguous jury instructions); Strawn \& Buchanan, Jury Confusion: $A$ Threat to Justice, 59 Judicature 478 (1976) (Florida study found jurors confused about jury instructions). See gener- 
awareness of gender dynamics, reinforced by such instructions, may help to produce the more effective evidence-driven discussion..$^{80}$

Currently, the judge plays a role in deciding which facts the jury will consider, and to some extent, the way in which the deliberations will be structured. The trial judge has discretion over procedural matters, which can obviously have substantive implications. For example, the trial judge's decisions about the admissibility of evidence determine which facts the jury even will be allowed to consider during its deliberations. ${ }^{91}$ The judge also can choose the verdict form and can offer instructions and comments on the evidence. ${ }^{22}$ Through the use of special verdicts, the judge can control the structure of the deliberation by requiring the jury to answer only the questions of fact posed by the judge. ${ }^{83}$ If the jury returns to the judge because it is unable to reach a verdict, then the judge can instruct it to continue its deliberations and to try, once again, to reach a verdict. ${ }^{94}$ After a trial, a judge may direct a verdict, or grant a judgment notwithstanding the verdict if the evidence was insufficient to support the jury's verdict, or

ally A. El.work, B. SAlts \& J. Alfini, Making JURy INSTructions Understandable (1982) (guidelines for improving jury instructions); Sales, Elwork \& Alfini, Improving Comprehension for Jury Instructions, in 1 Persprctives in Law \& Psychology: The Criminal Justice System 23 (B. Sales ed. 1977) (jury instructions' comprehensibility can be improved through attention to vocabulary, grammatical construction, and organization).

90. See supra notes 41-50 and accompanying text. Jurors might be particularly attuned to what the judge says because they are uncertain about how to perform their new role and look to the special knowledge and authority of the judge for guidance. Note, Judges' Nonverbal Behavior in Jury Trials: A Threat to Judicial Impartiality, 61 VA. L. Rev. 1266, 1278 (1975). In fact, the judge's influence is thought to be so strong that her instructions must be framed carefully (hence the reliance on patterned instructions) and can be reviewed stringently for any trace of partiality. See Andres v. United States, 333 U.S. 740, 765 (1948) (Frankfurter, J., concurring) ("Charging a jury is not a matter of abracadabra. No part of the conduct of a criminal trial lays a heavier task upon the presiding judge. The charge is that part of the whole trial which probably exercises the weightiest influence upon jurors."). A recent empirical study found that jurors are influenced not only by what the judge says, but also by the way in which she says it. Note, The Appearance of Justice: Judges' Verbal and Nonverbal Behavior in Criminal Jury Trials, 38 STAN. L. REv. 89 (1985) (judges may convey their expectations for trial outcome to jurors through subtle, nonverbal cues, such as facial expressions or tone of voice).

91. F. James \& G. Hazard, Civil Procedure \& 7.I0 (1985).

92. The judge can choose a general verdict with or without interrogatories or a special verdict. See 1 E. DevitT \& C. Bl.ackmar, supra note $81, \S 6.05$; see also Fed. R. Civ. P. $49 ; 9$ C. WRIGHT \& A. Miller, Federal Practice and Procedure: Civil $\$ \S 2512,2557$ (1971) (court has discretion to submit written interrogatories to jury along with general verdict; federal judges have discretion, which state judges do not always have, to comment on evidence).

93. Johnston, Jury Subornation Through Judicial Control, 43 LAW \& Contemp. ProBs., Autumn 1980, at 24, 28-29.

For example, Judge Berdon expressed a preference for the use of interrogatories to the jury to force the jurors to focus on facts and evidence before reaching any conclusions: "I specifically instruct [the jury] not to try to reach a verdict until they've answered all the interrogatories. . . . Something like that may really force them to focus on facts." Interview with Judge Robert Berdon, Connecticut Superior Court, in New Haven (Feb. 24, 1986).

94. If a jury has decided that it has reached a deadlock, then the judge can deliver an "Allen charge," which is "a sharp punch to the jury, reminding [the jurors] of the nature of their duty and the time and expense of a trial, and urging them to try again to reach a verdict. We specifically have approved the use of such a charge." United States v. Anderton, 679 F.2d 1199, 1203 (5th Cir. 1982) (citations omitted). 
grant a new trial if the evidence was contrary to the jury's verdict. ${ }^{95}$ The proposal in this Note to educate jurors is substantially less intrusive than such current practices. Moreover, through education, jurors will gain an awareness of the deliberation process that will allow them both to control their own deliberations and to perform their role more effectively.

\section{ConClusion}

Numerous empirical studies of mock juries all identify the same pattern: Women have a lower participation rate than men during deliberations. Because the jury carries out its tasks through the exchange of ideas communicated by words, active verbal participation is essential for finding the facts, applying the law to the facts, and rendering an accurate verdict that represents the values of the community. The jury's ability to perform these tasks effectively is fundamental to the fairness of our system of justice. The jury cannot perform its tasks effectively unless both women and men speak and listen to each other. Only then will the jury have a style of deliberation likely to elicit different points of view; only then will the jury have a full range of facts and perspectives to consider. If the court system fails to educate jurors about the effects of gender dynamics on the deliberation process, then the representativeness and accuracy of the jury will continue to be compromised. Courts should draw from studies in organizational behavior, as they have drawn from empirical studies in the past, to educate jurors about the dynamics of the jury, so that both men and women can participate fully during deliberations.

95. Johnston, supra note 93 , at $29-30,48$. 